\title{
Pockmarks in the fjords of Chilean Patagonia
}

\author{
J. A. DOWDESWELL ${ }^{1}$, E. K. DOWDESWELL ${ }^{1} \&$ C. RODRIGO ${ }^{2}$ \\ ${ }^{1}$ Scott Polar Research Institute, University of Cambridge, Cambridge CB2 1ER, UK \\ ${ }^{2}$ Department of Geology, Andrés Bello University, Quillota 980, Viña del Mar, Chile \\ *Corresponding author (e-mail: jd16@cam.ac.uk)
}

The fjords of Chilean Patagonia are areas of relatively rapid Holocene sediment delivery from glacial, glacifluvial and fluvial systems fed by substantial ice and snowmelt on the flanks of the Andean mountains. Many fjords are infilled by tens of metres of fine-grained, acoustically laminated sediment leading to a relatively flat and undifferentiated appearance of the fjord floor except where mass-wasting and turbiditycurrent processes are operating (e.g. daSilva et al. 1997; Araya-Vergara 1999, 2008; Boyd et al. 2008; Dowdeswell \& Vasquez 2013). In some areas, pockmarks have been observed on the floor of fjords, whose origin has been linked to the escape of fluids from the underlying sediments.

\section{Description}

During the analysis and interpretation of almost $27,000 \mathrm{~km}^{2}$ of multibeam bathymetric imagery from the fjords of Chile between $47^{\circ} 35^{\prime} \mathrm{S}$ and $50^{\circ} 17$ 'S (Fig. 1a), several relatively small areas of the fjord floor were identified to contain crater-like pockmarks (Dowdeswell \& Vasquez 2013). Three areas of pockmarks were found in the Angostura Inglesa and Paso del Indio channels between $48^{\circ} 57^{\prime}$ and $59^{\circ} 11^{\prime} \mathrm{S}$ (Fig. 1b-d) at water depths of $<160 \mathrm{~m}$, sometimes in groups of ten or more (Fig. 1c), or in more scattered patterns (Fig.1b, d). A number of pockmarks were observed to occur in linear to curvilinear chains or strings (Fig. 1c-d).

The dimensions of over 80 individual pockmarks were measured from swath-bathymetric data, which were gridded at $20 \mathrm{~m}$ resolution horizontally and had a vertical resolution of about $0.5 \mathrm{~m}$. The median width of the pockmarks, which were mainly circular to elliptical, was between 40 and $60 \mathrm{~m}$ and calculated median crater depth was 3 to $5 \mathrm{~m}$ (Dowdeswell \& Vasquez 2013). Maximum observed widths and depths were $130 \mathrm{~m}$ and $13 \mathrm{~m}$, respectively. A few pockmarks appear to be composites, where two or more individual craters have amalgamated (Fig. 1c). A sharp cutoff in the recorded minimum pockmark width at about $40 \mathrm{~m}$ is probably related to the resolution and gridding of the multibeam data, and suggests that some smaller-diameter craters may remain unidentified.

\section{Interpretation}

The crater-like pockmarks probably formed by fluid escape from the underlying sediments to the surface (Hovland \& Judd 1988). Most of the pockmarks appear to have relatively sharply defined rims, suggesting that they are not being buried by continuing sedimentation and may, therefore, be either actively developing, recently formed or preserved in areas of particularly low sediment delivery. We do not have the observations to distinguish between these possibilities, although the generally high rates of Holocene sedimentation measured in several Chilean fjords suggest that the third explanation is least likely (e.g. Boyd et al. 2008).

The linear to curvilinear chains of pockmarks, illustrated in Figure 1c-d, are probably linked to the presence of near-vertical faults or other zones of weakness in the underlying fjord sediments. Fluid migration associated with such zones can be identified in sub-bottom profiles by acoustic masking where reflections are distorted or disturbed, sometimes as chimney-like features within acoustically stratified sediments attributed to vertical fluid migration. No suitable acoustic records are available for the area of pockmarks around Angostura Inglesa and Paso del Indio, but a similar acoustic profile from Inutil Bay in Tierra del Fuego (Fig. 1a), further south in Patagonia and in an area of pockmarks, shows these chaotic vertical acoustic features clearly (Fig. 1e). Such masking is often associated with the scattering of acoustic energy by interstitial gas bubbles in the sediments. Zones of chaotic reflectors in nearby Marinelli Fjord, Tierra del Fuego, have been interpreted similarly (Boyd et al. 2008).

Pockmarks, produced by fluid escape from sediments that are often rich in decayed organic material or by the dissociation of subsea gas hydrates, are found on the floors of many high-latitude fjords and continental shelves (e.g. Hovland 1981; Syvitski et al. 1987; Solheim \& Elverhøi 1993; Bünz et al. 2012). Such crater-like seabed landforms are not restricted to the polar seas, however, and similar pockmarks are distributed through the shelf-seas of the world (Hovland \& Judd 1988).

We thank the Servicio Hidrografico y Oceanografico de la Armada de Chile (SHOA) for allowing use of their swath-bathymetric data.

\section{References}

ANDERSON, A. L. \& HAMPTON, L. D. 1980. Acoustics of gas-bearing sediments. I. Background. Journal of the Acoustical Society of America, 67, 1865-1889.

ARAYA-VERGARA, J. F. 1999. Secuencia de formas deposicionales submarinas en la fractura del Canal Messier, Patagonia Central. Invest. Mar, Valparaiso, 27, 39-52.

ARAYA-VERGARA, J. F. 2008. The submarine geomorphology of the Chilean Patagonian fjords and piedmonts. In Silva N. and Palma, S., (eds.), Progress in the Oceanographic Knowledge of Chilean Interior Waters, from Puerto Montt to Cape Horn, 25-27. Comite Oceanografico Nacional, Valparaiso, Chile.

BOYD, B. L., ANDERSON, J. B., WELLNER, J. S. \& FERNANDEZ, R. A. 2008. The sedimentary record of glacial retreat, Marinelli Fjord, Patagonia: regional correlations and climate ties. Marine Geology, 255, 165-178.

BÜNZ, S., POLYANOV, S., VADAKKEPULIYAMBATTA, S., CONSOLARO, C. \& MIENERT, J. 2012. Active gas venting through hydrate-bearing sediments on the Vestnesa Ridge, offshore W Svalbard. Marine Geology, 332, 189-197.

DaSILVA, J. L., ANDERSON, J. B. \& STRAVERS, J. 1997. Seismic facies changes along a nearly continuous $24^{\circ}$ latitudinal transect: the 
fjords of Chile and the northern Antarctic Peninsula. Marine Geology, 143, 103-123.

DOWDESWELL, J. A. \& VÁSQUEZ, M. 2013. Submarine landforms in the fjords of southern Chile: implications for glacimarine processes and sedimentation in a mild glacier-influenced environment. Quaternary Science Reviews, 64, 1-19.

HOVLAND, M., 1981. Characteristics of pockmarks in the Norwegian Trench. Marine Geology, 39, 103-117.

HOVLAND, M. \& JUDD, A. G. 1988. Seabed Pockmarks and Seepages: Impact on Geology, Biology and the Marine Environment.

London, Graham \& Trotman, 293 pp.

SOLHEIM, A. \& ELVERHØI, A. 1993. Gas-related sea floor craters in the Barents Sea. Geo-Marine Letters, 13, $235-243$.

SYVITSKI, J. P. M., BURRELL, D. C. \& SKEI, J. M. 1987. Fjords: Processes and Products. Springer, Berlin, 379 pp.
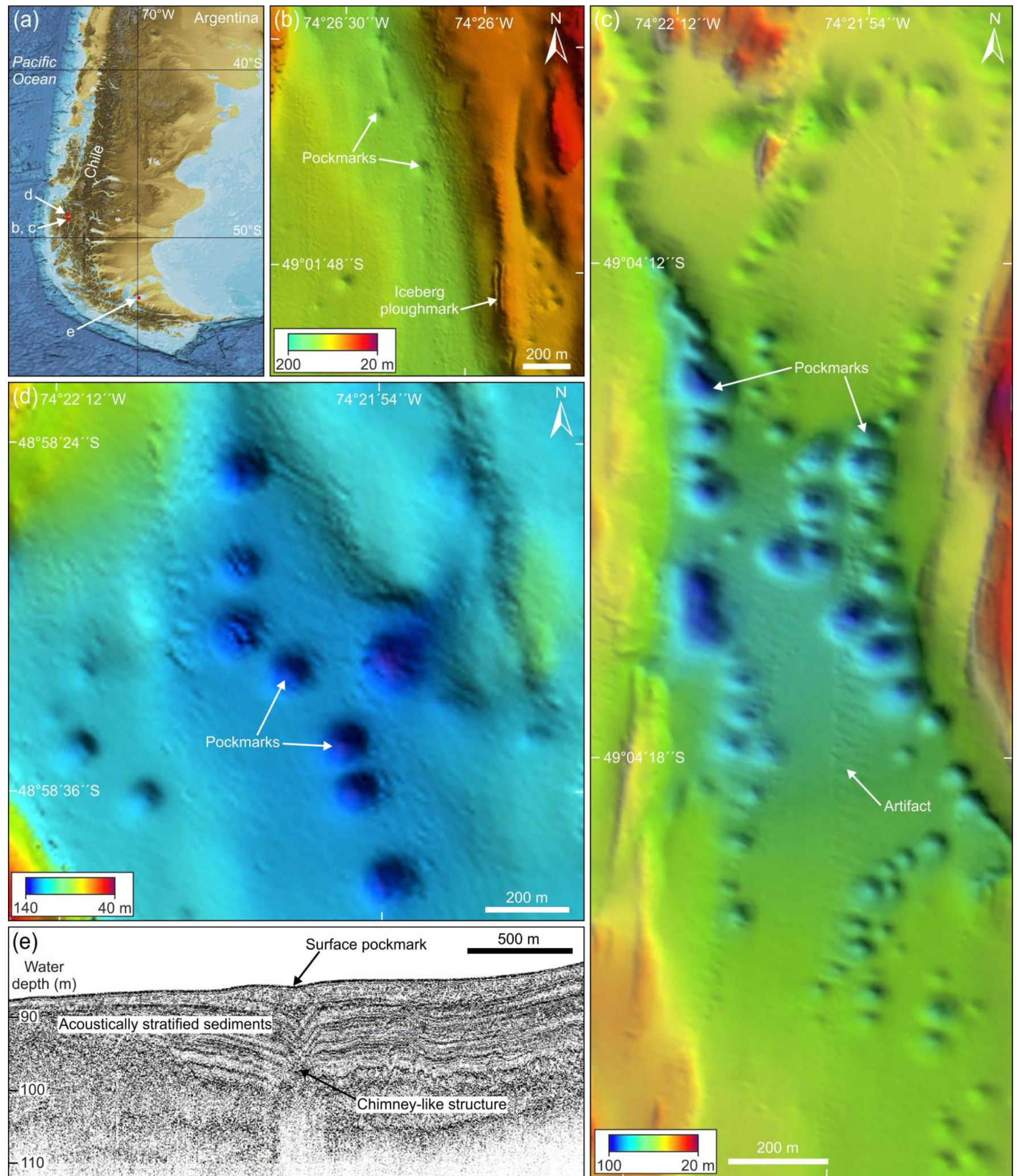

Fig. 1. (a) Location of study area in South America (red box; map from GEBCO 08). Crater-like pockmarks on the predominantly flat floor of two Chilean fjords (images modified from Dowdeswell \& Vasquez 2013). (b and c) Multibeam images from Paso del Indio (d) and Angostura Inglesa. Acquisition system Atlas Fansweep. Frequency $200 \mathrm{kHz}$. Grid-cell size $20 \mathrm{~m}$. (e) $3.5 \mathrm{kHz}$ sub-bottom acoustic profile from Inutil Bay, Tierra del Fuego (courtesy of A. Leventer from Cruise NBP1208). 